\title{
Evaluation of Perceived Stress Level and Emotional Eating Behaviors of Sports College Students During COVID-19 Pandemic
}

\author{
COVID-19 Pandemi Sürecinde Spor Bilimleri Fakültesi Öğrencilerin Stres Düzeyi \\ ve Duygusal Yeme Davranışlarının Değerlendirilmesi
}

\author{
Ramazan Güneşer ${ }^{1}$, Aydın Him ${ }^{2}$ \\ ${ }^{1}$ Bolu Abant Izzet Baysal University, Vocational School of Health, Bolu, Turkey \\ ${ }^{2}$ Bolu Abant İzet Baysal University, Faculty of Medicine, Department of Physiology, Bolu, Turkey. \\ Yazısma Adresi / Correspondence: \\ Ramazan Güneșer \\ Bolu Abant İzzet Baysal University, Vocational School of Health, Bolu, Turkey, \\ T: + 905054741204 E-mail : rmzngnsr@gmail.com \\ Geliş Tarihi / Received : 08.12.2020 Kabul Tarihi / Accepted : 17.06.2021 \\ Orcid : \\ Ramazan Güneșer https://orcid.org/0000-0001-7877-4397 \\ Aydın Him https://orcid.org/0000-0003-3279-1524 \\ ( Sakarya Tip Dergisi / Sakarya Med J 2021, 11(2):434-441 ) DOI: 10.31832/smj.871642
}

\begin{abstract}
Objective The aim of our study was to investigate the perceived stress level and emotional eating behaviors of sports college students during the COVID-19 pandemic.

Materials This study was conducted on 122 volunteer students studying at the Faculty of Sports Sciences of Bolu Abant Izzet Baysal University. The data was collected online through and Methods the socio-demographic data form, the Perceived Stress Scale, and the Emotional Eating Scale.

Results The perceived stress scale score average of the students was $28.93 \pm 7.54$, with $37.7 \%$ ( $\mathrm{n}=46)$ having a low stress level, $58.2 \%$ ( $\mathrm{n}=71)$ having a moderate stress level and $4.1 \%$ $(\mathrm{n}=5)$ having a high stress level. There was no significant difference between the groups in terms of emotional eating behavior scores $(\mathrm{p}=0,132)$. Both perceived stress level scores $(\mathrm{P}=0.044)$ and emotional eating behavior scores $(\mathrm{p}=0.001)$ of female students were significantly higher compared to male students. Both perceived stress scale scores $(\mathrm{p}=0.002)$ and emotional eating behavior scores $(\mathrm{p}=0.029)$ of the students with $\mathrm{BMI}<25$ were statistically higher compared to the students with $\mathrm{BMI}>25$.

Conclusion COVID-19 pandemic had a number of negative effects on students' stress levels and emotional eating behaviors. It is thought that quarantine measures that is applied to prevent transmission and spread of the disease, concerns about the disease and school education may contribute to these negative effects. During COVID-19 pandemic it is important to keep the immune system strong by preventing mood changes and related emotional eating behavior.

Keywords COVID-19; Perceived stress; Emotional eating; Quarantina; Circadian rhythm

Öz

Amaç Çalısmamızın amacı, COVID-19 pandemi sürecinde spor koleji öğrencilerinin algılanan stres düzeyi ve duygusal yeme davranışlarının araștırılmasıdır.

Gereçve Çalıșma, Bolu Abant İzzet Baysal Üniversitesi Spor Bilimleri Fakültesinde öğrenim gören 122 gönüllü öğrenci üzerinde gerçekleştirilmiştir. Veriler, sosyo-demografik veri formu, Algllanan Yöntemler Stres Ölçeği ve Duygusal Yeme Ölçeği aracilı̆̆lyla online olarak toplanmıştır.

Bulgular Öğrencilerin algılanan stres ölçeği puan ortalamalar $28,93 \pm 7,54$ idi ve \%37,7'si ( $n=46)$ düşük stres düzeyine, \%58,2'si (n=71) orta stres düzeyine ve \%4,1’i (n=5) yüksek stres düzeyine sahipti. Alglanan stres düzeyi kategorisine göre duygusal yeme davranıs puanlarının karşılaştırılmasında, gruplar arasında anlaml bir fark yoktu ( $p=0,132)$. Kız öğrencilerin hem algılanan stres düzeyi puanları $(P=0,044)$ hem de duygusal yeme davranıs puanları $(P=0,001)$ erkek öğrencilere kıyasla anlamlı șekilde yüksek bulundu. BKİ (Beden Kitle İndeksi) 25 ’ten küçük öğrencilerin hem algilanan stres ölçeği puanları ( $p=0,002)$ hem de duygusal yeme ölçeği puanları $(p=0,029)$ BKİ 25 'ten büyük öğrencilere kiyasla istatistiksel olarak anlamlı bulundu.

Sonuç COVID-19 pandemi süreci, öğrencilerin stres düzeyleri ve duygusal yeme davranıșları üzerine birtakım olumsuz etkilere neden olmuștur. Hastalı̆̆ın bulașması ve yayllmasını önlemek için uygulanan karantina tedbirlerinin, hastalı ve eğitim-öğretim süreci ile ilgili endişelerin bu olumsuzluklara katkısının olabileceği düşünülmektedir. COVID-19 pandemi sürecinde, değişen duygu durumu ve buna bağhı oluşabilecek duygusal yeme davranışımın önüne geçerek bağıșıllk sistemini güçlü tutmak büyük önem arz etmektedir.
\end{abstract}




\section{INTRODUCTION}

Due to COVID-19 pandemic, most people try to stay home for a while and stay isolated from society to protect themselves from the disease. It is reported by UNESCO that approximately 861.7 million students do not attend school due to COVID-19. ${ }^{1}$ These circumstances negatively affect people's physical and mental behavior. Epidemics of infectious diseases can affect both the physical health of infected people and the psychological health and well-being of the uninfected population. Earlier studies have indicated that the outbreak of new infectious diseases, such as severe acute respiratory syndrome (SARS), can increase anxiety, depression and stress level among people. ${ }^{2} \mathrm{COV}$ ID-19 outbreak is a stressful condition for people and fear and anxiety about the disease can lead to intense emotions in adults and children. In addition, being unable to leave home due to preventive measures can lead to high stress, anxiety and mental distress. ${ }^{3}$ Common complaints during quarantine include confusion, concentration difficulties, fear, anger, feelings of guilt or mourning, lethargy, feeling exhausted, insomnia. Acute stress disorder, post-traumatic stress disorder, major depression, generalized anxiety disorder, adjustment disorder are among the most common mental disorders during quarantine. ${ }^{4}$ COVID-19 outbreak requires strict isolation strategies to prevent the spread of the virus. However, isolation of people, fear of getting infected, quarantine and stigmatization, mental health burden due to the potential (mis) information overload about the disease create risk factors for stress, anxiety and depression. It is well known that chronic stress is a major immune modulator and thus directly affects the likelihood of infection. ${ }^{5}$ The role of unpredictability, uncertainty, severity of disease, misinformation and social isolation related to COVID-19 in contributing to stress and mental morbidity has been recently emphasized. ${ }^{6}$

Quarantine causes the person to stay away from their routine life, causing both changes in mood and a more sedentary life. ${ }^{7}$ The physical and psychological state experienced during a pandemic causes changes in mood and nutrition- al behavior. ${ }^{8}$ There is a relationship between individuals' eating habits and their moods. Specific emotions such as anger, fear, sadness or joy have been found to be effective in changing eating response and eating behavior of the individuals. ${ }^{9}$ Besides the biological need to eat, there is also psychological importance. Individuals may eat more than usual when they feel under pressure, anxious, stressed or angry. This is due to psychological need rather than biological need. Similarly, some individuals do not eat at all in situations where they are excited or over-stressed, which is also an effect of emotional states on eating. ${ }^{10}$ During the COVID-19 pandemic, due to the absence of normal social rhythms such as socialization and work life, our biological clock has difficulties forming regular rhythms. Maintaining a regular routine, exercise, sleep, light adjustment, nutrition and stress management are recommended in regulating our circadian rhythm. ${ }^{11}$ It is reported that the irregularity of the circadian rhythm, which is an important factor for immune system optimization, may make individuals more susceptible to infections. ${ }^{12}$ It is important to optimize the timing of environmental stimuli that has important impact on the circadian clock, such as sleep, body temperature, light, nutrition, physical activity and exercise, in order to prevent diseases and to make the circadian clock work in a more coordinated manner. ${ }^{13}$ This study investigated the stress levels and emotional eating behaviors of sports college students during COVID-19 pandemic.

\section{MATERIALS and METHODS}

The ethical permission required for the research was obtained from Bolu Abant Izzet Baysal University Clinical Research Ethics Committee (Decision date/no: 22.06.2020/142). The study was designed in accordance with the principles of the Helsinki Declaration. The study was conducted on students studying at the Faculty of Sports Sciences of Bolu Abant Izzet Baysal University. Informed consent was obtained from all participants. The research is designed as a descriptive study and the data was obtained in June 2020 using online data collection tools (Google Docs). The data of the study was collect- 
ed through the questionnaire and forms called "Personal Data Form", "Perceived Stress Scale (PSS)", "Emotional Eating Scale (EES)". Students who filled out the questionnaires correctly and completely were included in the study $(n=122)$. Students with psychological disorders and eating disorders were not included in the study.

PSS was developed by Cohen, Kamarck, and Mermelstein (1983). ${ }^{14}$ The scale, which consists of a total of 14 items, is designed to measure the degree to which certain situations in one's life are perceived as stressful. The scale, which is of the likert type 5 , evaluates each item to degrees ranging from "never (0)" to "very often (4)". Seven of the positive expression items of the scale are scored in reverse. Baltaş et al (1998) and Eskin et al (2013) conducted standardization studies for the use of the scale in Turkey. The total score from the scale indicates stress level of the person. The score between 11 and 26 is low stress level, 27-41 is moderate stress level, 42-56 indicates high-stress level. ${ }^{15,16} \mathrm{EES}$ is a unidimensional one-factor 14-item scale developed by Doğan et al. (2011) to assess emotional eating behavior in adults. Cronbach's alpha internal consistency of the scale was 0.94 and found to be to be reliable and valid for determining the emotional eating levels of adults. ${ }^{17}$

\section{Statistical Analysis}

While categorical variables are expressed as percentage and frequency distributions, continuous variables are expressed as mean and standard deviation values. The normality distribution of the data was examined by the Kolmogrov Smirnov test. The independent sample t test was used in the analysis of normally distributed data while the Mann Whitney U test was used in the analysis of non-normally distributed data. The Kruskal-Wallis test was used to compare three and more group. Comparison of categorical data was made with chi-square test. $\mathrm{p}<0.05$ values were considered statistically significant. The data was evaluated through the SPSS statistical package program.

\section{RESULTS}

Descriptive statistics for the participants according to gender are given in Table 1 . While $54.1 \%(n=66)$ of the participants was female $45.9 \%(n=56)$ was male students. The mean age, height, weight and body mass index (BMI) of male students were higher compared to female students $(\mathrm{p}<0.005)$. There was no significant difference between male and female students in terms of smoking habits (Table 1).

\begin{tabular}{|c|c|c|c|c|c|c|c|}
\hline & \multicolumn{2}{|c|}{ Female } & \multicolumn{2}{|c|}{ Male } & \multicolumn{2}{|c|}{ Total } & \\
\hline & $\mathrm{N}=66$ & $54,1 \%$ & $\mathrm{~N}=56$ & $45,9 \%$ & $\mathrm{~N}=122$ & $100 \%$ & \\
\hline & \multicolumn{2}{|c|}{ Mean \pm Sd } & \multicolumn{2}{|c|}{ Mean $\pm S d$} & \multicolumn{2}{|c|}{ Mean \pm Sd } & $\mathbf{P}$ \\
\hline Age & \multicolumn{2}{|c|}{$19,98 \pm 1,78$} & \multicolumn{2}{|c|}{$21,11 \pm 2,51$} & \multicolumn{2}{|c|}{$20,50 \pm 2,21$} & $0,011^{*}$ \\
\hline $\begin{array}{l}\text { Height } \\
\text { (cm) }\end{array}$ & \multicolumn{2}{|c|}{$164,52 \pm 4,73$} & \multicolumn{2}{|c|}{$177,52 \pm 6,55$} & \multicolumn{2}{|c|}{$170,48 \pm 8,59$} & $<0,001^{* *}$ \\
\hline $\begin{array}{l}\text { Weight } \\
(\mathrm{kg})\end{array}$ & \multicolumn{2}{|c|}{$55,53 \pm 5,37$} & \multicolumn{2}{|c|}{$75,91 \pm 11,39$} & \multicolumn{2}{|c|}{$64,89 \pm 13,36$} & $<\mathbf{0 , 0 0 1}{ }^{*}$ \\
\hline BMI & \multicolumn{2}{|c|}{$20,52 \pm 1,81$} & \multicolumn{2}{|c|}{$24,02 \pm 2,75$} & \multicolumn{2}{|c|}{$22,13 \pm 2,88$} & $<0,001^{*}$ \\
\hline \multirow[t]{3}{*}{$\begin{array}{l}\text { Smok- } \\
\text { ing }\end{array}$} & Yes & No & Yes & No & Yes & No & \\
\hline & 23 & 43 & 17 & 39 & 40 & 82 & \multirow{2}{*}{$0,598^{* * *}$} \\
\hline & $18,9 \%$ & $35,2 \%$ & $13,9 \%$ & $32,0 \%$ & $32,8 \%$ & $67,2 \%$ & \\
\hline
\end{tabular}

The comparison of PSS and EES scores of participants according to gender revealed that both PSS and EES scores of female students were significantly higher compared to male students ( $\mathrm{p}=0,044$ and $\mathrm{p}=0.001$, respectively) (Table 2).

\begin{tabular}{|l|c|c|}
\hline \multicolumn{3}{|l|}{$\begin{array}{l}\text { Table 2. Comparison of perceived stress and emotional eating } \\
\text { scores according to gender }\end{array}$} \\
\hline & $\begin{array}{c}\text { PSS score } \\
\text { Mean } \pm \text { Sd }\end{array}$ & $\begin{array}{c}\text { EES score } \\
\text { Mean } \pm \text { Sd }\end{array}$ \\
\hline $\begin{array}{l}\text { Female } \\
\text { N=66 54.1\% }\end{array}$ & $30,29 \pm 7,04$ & $37,52 \pm 14,93$ \\
\hline $\begin{array}{l}\text { Male } \\
\text { N=46 45,9\% }\end{array}$ & $27,34 \pm 7,87$ & $28,43 \pm 13,26$ \\
\hline $\mathbf{P}$ & $\mathbf{0 , 0 4 4}^{*}$ & $\mathbf{0 , 0 0 1}^{*}$ \\
\hline${ }^{*}$ Mann Whitney U test \\
\hline
\end{tabular}

In comparison of EES scores of participants with different 
perceived stress levels, the difference was not statistically significant although EES score increased as the perceived stress level increased (Table 3).

\begin{tabular}{|c|c|c|c|c|}
\hline $\begin{array}{l}\text { Perceived } \\
\text { stress } \\
\text { level }\end{array}$ & $\begin{array}{c}\begin{array}{c}\text { low } \\
(n=46)\end{array} \\
37,7 \%\end{array}$ & $\begin{array}{c}\text { moderate } \\
(\mathrm{n}=71) \\
58,2 \%\end{array}$ & $\begin{array}{c}\text { high } \\
(\mathrm{n}=5) \\
4,1 \%\end{array}$ & $\mathrm{P}$ \\
\hline EES score & $32,41 \pm 13,62$ & $33,03 \pm 15,38$ & $46,40 \pm 14,64$ & $0,132^{*}$ \\
\hline
\end{tabular}

There was a low positive correlation between PSS and EES scores $(r=0.121)$, but this association was not statistically significant $(\mathrm{p}=0.184)$.

Both PSS and EES scores of participants with $\mathrm{BMI}<25$ (normal weight and underweight) were significantly higher compared to BMI>25 (overweight and obese) participants (Table 4 ).

\begin{tabular}{|l|c|c|}
\hline \multicolumn{3}{|c|}{ Table 4. Comparison of PSS and EES scores according to BMI } \\
\hline & $\begin{array}{c}\text { PSS score } \\
\text { Mean } \pm \text { Sd }\end{array}$ & $\begin{array}{c}\text { EES score } \\
\text { Mean } \pm \text { Sd }\end{array}$ \\
\hline $\begin{array}{l}\text { BKI }<\mathbf{2 5} \\
\mathbf{N}=\mathbf{1 0 4} \mathbf{8 5 , 2} \%\end{array}$ & $29,97 \pm 6,88$ & $34,65 \pm 15,04$ \\
\hline $\begin{array}{l}\text { BKI }>\mathbf{2 5} \\
\mathbf{N}=\mathbf{1 8 ~} \mathbf{1 4 , 8} \%\end{array}$ & $22,94 \pm 8,56$ & $25,78 \pm 11,25$ \\
\hline $\mathbf{P}$ & $\mathbf{0 , 0 0 2}$ & $\mathbf{0 , 0 2 9}^{*}$ \\
\hline * Mann Whitney U test \\
\hline
\end{tabular}

The average values of PSS and ESS scores and the descriptive statistics of the participants are given in the Table 5.

\begin{tabular}{|l|c|c|c|c|}
\hline \multicolumn{5}{|l|}{ Table 5. Descriptive statistics of scales } \\
\hline Scale & $\begin{array}{c}\text { Item } \\
\text { number }\end{array}$ & $\begin{array}{c}\text { Received } \\
\text { min.-max. } \\
\text { score }\end{array}$ & Mean \pm Sd & $\begin{array}{c}\text { Scale } \\
\text { min.- max. } \\
\text { scores }\end{array}$ \\
\hline PSS & 14 & $8-48$ & $28,93 \pm 7,54$ & $0-56$ \\
\hline EES & 14 & $14-70$ & $33,34 \pm 14,84$ & $14-70$ \\
\hline
\end{tabular}

\section{DISCUSSION}

COVID-19 is a public health issue that is considered a pandemic by the World Health Organization and threatens the entire world. In the course of the pandemic, practices some measures such as social isolation and quarantine are taken to prevent the spread of the disease. However, these conditions lead to various mental problems like anxiety and depressive symptoms in individuals and negatively affect community life. ${ }^{18}$ It is also reported that the stress caused by the quarantine process is associated with greater intake of nutrients and energy. ${ }^{19}$ It has been stated that dietary habits are affected by stress and distress, and that changes in nutrient intake can be a natural response to stress through both psychological and physiological mechanisms. ${ }^{20}$

According to our findings, a significant proportion of the students who participated in the study was found to have moderate stress levels. Cao et al. (2020) reported that $24.9 \%$ of college students experienced anxiety due to the COVID-19 outbreak, suggesting that this anxiety may have been caused by the increasing distances between people from quarantine. ${ }^{21}$ Xiao et al (2020) reported that isolated individuals had high levels of anxiety and stress, and poor quality of sleep. ${ }^{22}$ Due to the COVID-19 pandemic, face-to-face education at most universities has been abandoned and the education was shifted to distance learning via online platforms. This new education method caused the students to experience stress related to participation in online courses, assessment and graduation. ${ }^{23}$ The increase in stress and anxiety levels caused by quarantine and social isolation is not limited to students alone. Studies report that various groups, such as the general population and health workers, also have increased levels of stress and anxiety. A study found that in the first phase of the COVID-19 outbreak in China, more than half of participants rated the psychological impact as moderate to severe, and about one-third reported moderate to severe anxiety. ${ }^{24} \mathrm{~A}$ study on individuals who isolated themselves for 14 days found that low levels of social capital were associated with 
increased levels of anxiety and stress, and also anxiety was associated with both stress and low sleep quality. ${ }^{22}$ Our findings are consistent with the literature and show that quarantine and social isolation during the COVID-19 pandemic process raises students' stress levels. We believe that this increase in stress level may have been caused by a number of reasons, such as students' disengagement from their routines, social isolation, non-socialization, changes in training and exam styles. Although students' stress levels have increased, it is noted that the number of students with high stress levels is relatively small. Şener (2018) reported that taking sports training can have an effect on decreasing individuals' stress level by contributing to the perception of good body image and well-being. ${ }^{25}$ Çelik et al. (2020) concluded that men had better positive thinking skills than women, and athletes had better positive thinking skills than non-sportive people and reported that regular sports would improve positive thinking skills. ${ }^{26}$ Considering the positive effects of sport and physical activity on stress; The reason for the the relatively low number of students experiencing high stress, despite the various factors that put great pressure and stress on the students during the quarantine process, could be sports education they received at university.

Activation of the hypothalamo-pituitary-adrenocortical axis, a physiological reaction to stress, constitutes the primary hormonal response to homeostatic struggle through the release of glucocorticoids. ${ }^{27}$ Nutrients are thought to cause mood improvement in individuals by disrupting stress response through some physiological mechanisms. ${ }^{28}$ The relationship between stress and emotional eating behavior that develops due to a number of emotions is known. Emotional eating behavior is more commonly considered as a response behavior to stress situations. Exposure to high stress, especially after natural disasters, can affect eating behavior. ${ }^{29}$ The COVID-19 pandemic threatens human health by affecting the entire world. The constant flow of information about COVID-19 disease during the quarantine process causes individuals to be- come anxious and their stress levels to increase. This can trigger emotional eating behavior and lead to high food intake. ${ }^{8}$ According to our results, the difference between the students' EES scores relative to their perceived stress levels was not significant. Çakaroğlu et al (2020) reported that sports college students had less social appearance anxiety and were slightly more anxious about the discipline of eating, awareness and conscious nutrition. ${ }^{30}$ There was no significant change in emotional eating behaviors as the perceived stress levels of the students increase and the majority of the students was in the normal range in terms of BMI values, which could be because of their interest in eating discipline and conscious nutrition as well as their concern about social appearance and changes in body image perception after weight gain due to emotional eating behavior.

Female students had higher PSS and EES scores compared to male students. Consistent with our findings, Tan and Chow (2014) found that female participants had higher perceived stress levels and emotional eating behaviors compared to men and men's BMI values were also significantly higher. ${ }^{31}$ In another study, it was reported that women scored higher in terms of emotional eating and men scored higher in terms of conscious eating. ${ }^{30}$ It has been noted that women exhibit more emotional eating behavior using more emotion regulation strategy. ${ }^{32}$ We conclude that the stress caused by a global event such as the COVID-19 pandemic affects female students more and they exhibit more emotional eating behaviors to cope with the stress associated with it. In addition, curfew restrictions were imposed on individuals under the age of 20 in Turkey starting on 4 April $2020 .^{33}$ According to our findings, the average ages of students were under 20 years $(19.98 \pm 1.78)$ for females and over 20 years $(21.11 \pm 2.51)$ for males. Consistent with our results, it appears that female students remain more at home than men due to curfew limitation and are more exposed to the negative effects of quarantine on stress and emotional eating behavior. The mean BMI of female students was significantly lower than 
that of male students, and the BMI value of male students was close to the overweight group. Although emotional eating behavior is often associated with excessive weight or obesity, Nguyen-Rodriguez et al. (2008) emphasized the relationship between perceived stress and emotional eating and that emotional eating was not just a problem for overweight and obese people. They thought that individuals with any weight could use eating as a strategy in coping with stress, but those who kept their weight within the normal range might engage in certain protective or compensatory behaviors. They reported that individuals who overate due to stress were able to eat less on the next day or exercise to compensate for their extra calorie intake. They also note that those people who are not yet overweight may develop excess weight if their emotional eating behavior persists. ${ }^{34}$ Consistent with this study, we found that female students had lower BMI values compared to male students and exhibited higher emotional eating behavior. We also found that individuals with $\mathrm{BMI}<25$ had high perceived stress levels and emotional eating behavior scores. Our results are similar to and support the study of Nguyen-Rodriguez et al (2008).

There are many studies reporting that the frequency of smoking in athletes is quite high. ${ }^{35}$ Our findings also suggest that smoking among students is high. A considerable portion of participants $(32,8 \%)$ reported smoking, with no significant difference between male and female students. Smoking has been reported to increase the risk of viral infection, including COVID-19 disease, and is also associated with the frequency of the disease and severity of the clinical outcome. ${ }^{36}$ The frequency of smoking among the students involved in our study is not desirable in terms of COVID-19, and we believe that smoking should be avoided in order to reduce the risk of the disease.

During the COVID-19 pandemic, individuals were socially isolated and had to carry out most of their work from their homes in order to protect themselves from the disease and prevent its spread. Students switched from face- to-face education to online education and followed the assessment of education in the home environment. A variety of factors such as changing habits, going away from the routine, social distancing, and anticipatory anxiety create stress on people. The increase in quarantine-related stress and nutrient intake causes the individual to go into a vicious cycle and disrupts sleep patterns. Regular sleep is directly associated with melatonin, a natural antioxidant hormone. ${ }^{37}$ In short, the pandemic period can prevent the formation of regular biological rhythms. Regular circadian rhythm is known to be associated with a strong immune system. The importance of circadian rhythm optimization is emphasized in the quarantine process to protect against diseases and to keep the immune system strong. The management of stress and nutrition is important in regulating biological rhythms. It is stated that many factors cause stress during the COVID-19 pandemic and psychological stress can increase infection severity by adverse effects similar to those brought by COVID-19 infection, and also the importance of stress management in reducing infection severity and associated deaths is emphasized. ${ }^{38}$ Although there is not enough data on BMI for patients with COVID-19 infection, it should be kept in mind that obesity has an important role in the COVID-19 pandemic. Obesity, as with other respiratory diseases, plays an important role in the pathogenesis of COVID-19 disease. ${ }^{39}$ Furthermore, preliminary data showed an increased risk of severe COVID-19 in people with obesity. ${ }^{40}$ The risk of social isolation and inadequate physical activity during the quarantine is a major problem in the COVID-19 pandemic that can lead to individuals gaining weight. A study comparing levels of nutrient intake and physical activity in the early phase of the COVID-19 outbreak (March/April) and earlier periods (2018 and 2019) found that there was increased nutrient uptake for women and decreased physical activity for both men and women after the pandemic. With these results, it has been reported that isolation measures can have detrimental consequences for physical and mental well-being with the potential to affect long-term nutrition and activity patterns. ${ }^{41}$ However, the COVID-19 pandem- 
ic affects people's psychological health alongside physical health, increasing the risk of stress-related eating behavior. ${ }^{42}$ Physical activity and exercise are reported to have an immune-boosting effect and can also help prevent a variety of conditions that may make individuals more susceptible to severe COVID-19, such as obesity, diabetes, hypertension, and serious heart diseases. ${ }^{43}$

Our study was conducted on students with sporting discipline who were physically active during the school term until the beginning of the quarantine process. As the literature shows, sportive individuals exhibit more positive behaviors on stress and eating. It is thought that their sporting activities and the sports education they received contributed greatly to this positive effect. Stress and obesity are understood to have negative effects on the development and severity of COVID-19 disease. On the contrary physiological biological rhythms and a strong immune system play a large role in reducing viral infections, including COVID-19. In this context, stress management against adversities during quarantine periods, prevention of emotional eating behaviors and awareness of the importance of establishing regular biological rhythms for a strong immune system are of great importance for protection from COVID-19 disease.

\section{Ethical permission}

The ethical permission required for the research was obtained from Bolu Abant Izzet Baysal University Clinical Research Ethics Committee (Decision date/no: 22.06.2020/142).

\section{Conflict of interest}

The authors declare that there is no potential conflicts of interest.

\section{Acknowledgement}

Authors would like to thank Dr. Oya Kalaycıŏlu, Department of Biostatistics and Medical Informatics, Faculty of Medicine, Bolu Abant Izzet Baysal University for

\section{her contributions.}

The study has no relationship with a sponsor or a commercial firm.

Both authors read and approved the final manuscript. 
Sakarya Med J 2021;11(2):434-441

GÜNEŞER et al., Effects of COVID-19 pandemic on Sports College Students

\section{References}

1. Hammami A, Harrabi B, Mohr M, Krustrup P. Physical activity and coronavirus disease 2019 (COVID-19): specific recommendations for home-based physical training. Managing Sport Leisure 2020; 20(0): 1-6. doi: 10.1080/23750472.2020.1757494.

2. Wu KK, Chan SK, Ma TM. Posttraumatic stress, anxiety, and depression in survivors of severe acute respiratory syndrome (SARS). J Trauma Stress 2005; 18(1):39-42. doi:10.1002/ jts.20004.

3. Centers for disease control and prevention. Coronavirus Disease 2019 (COVID-19) Stress and Coping. Available at: https://www.cdc.gov/coronavirus/2019-ncov/daily-life-coping/ managing-stress-anxiety.html. Cited: $2019 \mathrm{Jul} 5$.

4. Türkiye Psikiyatri Derneği. Karantinanın Ruhsal Etkileri ve Koruyucu Önlemler. Available at: https://www.psikiyatri.org.tr/TPDData/Uploads/files/KarantinaCOVID.pdf. Cited: 2019 Jul 2.

5. Burtscher J, Burtscher M, Millet GP. (Indoor) isolation, stress and physical inactivity: vicious circles accelerated by Covid-19. Scand J Med Sci Sports 2020; 10.1111/sms.13706. doi:10.1111/sms.13706.

6. Zandifar A, Badrfam R. Iranian mental health during the COVID-19 epidemic. Asian J Psychiatr 2020; 51: 101990. doi:10.1016/j.ajp.2020.101990.

7. Moynihan AB, Van Tilburg WA, Igou ER, Wisman A, Donnelly AE, Mulcaire JB. Eaten up by boredom: consuming food to escape awareness of the bored self. Front Psychol 2015; 6: 369. doi:10.3389/fpsyg.2015.00369

8. Eskici G. COVID-19 Pandemisi: karantina için beslenme önerileri. Anatol Clin 2020; 25(1):124-9.

9. Economy, AM. Exploring the association between emotions and eating behavior. Winona State University, Master's thesis, 2013, USA.

10. Macht M. Characteristics of eating in anger, fear, sadness and joy. Appetite 1999; 33(1): 129-139. doi:10.1006/appe.1999.0236.

11. Güzel Özdemir P, Özışı M. COVID-19 and circadian rhythm. Anatolian Journal of Psychiatry 2020; 20(3): 336 .

12. Bryson WJ. Circadian rhythm sleep-wake disorders and the COVID-19 pandemic. J Clin Sleep Med 2020;16(8):1423. doi:10.5664/jcsm.8540

13. Ceylan Hİ, Saygı Ö, Türkcü ÜÖ. Obezite, Aerobik Egzersiz ve Sirkadiyen Ritim İlișkisi. İstanbul: Gece Akademi; 2011.

14. Cohen S, Kamarck T, Melmerstem R. A Global Measure of Perceived Stress. Journal of Health and Social Behavior 1983; 24: 385-96.

15. Baltaş Z, Atakuman Y, Duman Y. Standardization of the Perceived Stress Scale: Perceived Stress in Turkish Middle Managers. Stress and Anxiety Research Society 19th International Conference, 1988, İstanbul.

16. Eskin M, Harlak H, Demirkıran F Dereboy Ç. Algılanan stres ölçeğinin Türkçe’ye Uyarlanmast: Güvenirlik ve geçerlik analiz. Yeni Symposium Journal 2013; 51(13): 132- 140.

17. Doğan T, Gö̧̧et Tekin E, Katrancioğlu A. Feeding your feelings: A self-report measure of emotional eating. Procedia Social and Behavioral Sciences 2011; 15: 2074-2077.

18. Tecirli ND, Ucuz G, Özel F. Isolation, Quarantine, Social Distancing and Mental Health. The Bulletin of Legal Medicine 2020; 25: 32-8.

19. Muscogiuri G, Barrea L, Savastano S, Colao A. Nutritional recommendations for COVID-19 quarantine. Eur J Clin Nutr 2020; 74(6): 850-1. doi:10.1038/s41430-020-0635-2.

20. Naja F, Hamadeh R. Nutrition amid the COVID-19 pandemic: a multi-level framework for action. Eur J Clin Nutr 2020; 74(8): 1117-21. doi:10.1038/s41430-020-0634-3.

21. Cao W, Fang Z, Hou G, Han M, Xu X, Dong J et al. The psychological impact of the COVID-19 epidemic on college students in China. Psychiatry Res 2020; 287:112934. doi:10.1016/j.psychres.2020.112934

22. Xiao H, Zhang Y, Kong D, Li S, Yang N. Social Capital and Sleep Quality in Individuals Who Self-Isolated for 14 Days During the Coronavirus Disease 2019 (COVID-19) Outbreak in January 2020 in China. Med Sci Monit 2020; 26: e923921. doi:10.12659/MSM.923921.

23. Sahu P. Closure of Universities Due to Coronavirus Disease 2019 (COVID-19): Impact on Education and Mental Health of Students and Academic Staff. Cureus 2020; 12(4): e7541. doi.org/10.7759/cureus.7541.
24. Wang C, Pan R, Wan X, Tan Y, Xu L, Ho C et al. Immediate Psychological Responses and Associated Factors during the Initial Stage of the 2019 Coronavirus Disease (COVID-19) Epidemic among the General Population in China. Int J Environ Res Public Health 2020; 17(5): 1729. doi:10.3390/ijerph17051729.

25. OA Șener. Spor Eğitimi Alan Bireylerde Vücut İmajı, Benlik Tasarımı ve Stres Düzeyi. Uluslararası Sosyal Araștırmalar Dergisi 2018; 11,60.

26. Çelik OB, Esentürk OK, İlhan EL. Sporcularla Sedanter Bireylerin Olumlu Düşünme Becerileri Üzerine Bir Karşllaștırma. Ulusal Spor Bilimleri Dergisi 2020; 4(1): 50-8.

27. Herman JP, McKlveen JM, Ghosal S, Kopp B, Wulsin A, Makinson R et al. Regulation of the Hypothalamic-Pituitary-Adrenocortical Stress Response. Comprehensive Physiology 2016; 6(2): 603-21. https://doi.org/10.1002/cphy.c150015.

28. E Tanrıverdi. Üniversite Öğrencilerinin Duygusal Yeme Davranışlarının ve Duygusal İștahlarının İncelenmesi: Cağ Üniversitesi, Yüksek Lisans Tezi, 2020, İstanbul.

29. Serin $Y$, Şanlıer $N$ (2018). Duygusal yeme, besin alımını etkileyen faktörler ve temel hemşirelik yaklaşımları. J Psychiatric Nurs 2018; 9(2): 135-46.

30. Çakaroğlu D, Ömer EH, Arslan C. Üniversite Öğrencilerinin Yeme Tutumu, Yeme Farkıdalı̆ı ve Sosyal Görünüş Kaygısının Değerlendirilmesi (Siirt İli Örneği). Beden Eğitimi ve Spor Bilimleri Dergisi 2020; 14(1): 1-12.

31. Tan CC, Chow CM. Stress and emotional eating: The mediating role of eating dysregulation. Personality and Individual Differences 2014; 66:1-4.

32. Larsen JK, van Strien T, Eisinga R, Engels RC. Gender differences in the association between alexithymia and emotional eating in obese individuals. J Psychosom Res 2006; 60(3): 237243. doi:10.1016/j.jpsychores.2005.07.006

33. Budak F, Korkmaz Ș. COVID-19 Pandemi Sürecine Yönelik Genel Bir Değerlendirme: Türkiye Örneği. Sosyal Araștırmalar ve Yönetim Dergisi 2020; 1: 62-79.

34. Nguyen-Rodriguez ST, Chou CP, Unger JB, Spruijt-Metz D. BMI as a moderator of perceived stress and emotional eating in adolescents. Eat Behav 2008; 9(2): 238-46. doi:10.1016/j. eatbeh.2007.09.001.

35. Aslan H, Erdağı K, Ișılk B, Erdoğan M, Güvenç A. Genç Sporcu ve Antrenörlerde Sigar İçme Alışkanlık ve Davranışları. Mediterranean Journal Of Humanities 2017; 7(1): 41-55.

36. Sönmez Ö, Tașdemir ZA, Kara HV, Akçay Ș. COVID-19 ve Tütün. Corona Virüs Hastalı̆̆ 2019. Eurasian Journal of Pulmonology 2020; 22-27.

37. Cetin E. Melatonin ve Bağıșılklk Sistemi. Erciyes Üniv Vet Fak Derg 2005; 2(2): 119-123.

38. Anderson G. Psychological Stress and Covid-19: Interactions with Gut Microbiome and Circadian Rhythm in Driving Symptom Severity. Braz J Psychiatry 2020;doi:1111./1111 (in press).

39. Kassir R. Risk of COVID-19 for patients with obesity. Obesity reviews: an official journal of the International Association for the Study of Obesity 2020; 21(6): e13034. https://doi. org/10.1111/obr.1303436

40. Stefan, N, Birkenfeld AL, Schulze MB, Ludwig DS. Obesity and impaired metabolic health in patients with COVID-19. Nat Rev Endocrinol 2020; 16: 341-2. https://doi.org/10.1038/ s41574-020-0364-6.

41. Gallo LA, Gallo TF, Young SL, Moritz KM, Akison LK. The Impact of Isolation Measures Due to COVID-19 on Energy Intake and Physical Activity Levels in Australian University Students. Nutrients 2020; 12(6): 1865 doi:10.3390/nu12061865.

42. Gürbüz P. COVID-19 and Obesity: A Systematic Review. Journal of Inonu University Health Services Vocational School 2020; 8: 506-14. doi: 10.33715/inonusaglik.735600.

43. Woods J, Hutchinson N, Powers S, Roberts W, Gomez Cebrera M, Radak Z et al. The CO VID-19 pandemic and physical activity. Sports Medicine and Health Science 2020; 2(2): 55-64. 